\title{
Institutional Participation and Earnings Information Quality: Empirical Evidence from China
}

\author{
Cheng Min \\ SHU-UTS SILC Business School, \\ Shanghai University, Shanghai, P.R.China
}

Doi:10.19044/esj.2018.v14n25p308 URL:http://dx.doi.org/10.19044/esj.2018.v14n25p308

\begin{abstract}
Recently many scholars are greatly concerned about the influence of institutional investors on companies' earnings information quality. Institutional investors have strong and professional team. With big fund stake on listed companies, institutional investors are theoretically thought of playing active role in supervising companies to ensure their investment safety and return. Much evidence has showed that institutional investors are becoming active institutional participation from past passive shareholders. The characteristics of institutional show great advantages on exerting their effect on corporate governance. Correspondingly positive behavior of institutional investors will influence the degree of the accounting information quality. Based on this concept, institutional investors can discover in a timely and effective manner problems existing in the accounting information disclosure. As a result, this article examines whether institutional investors as active shareholders can participate in corporate governance in order to improve companies' accounting information quality.
\end{abstract}

Keywords: Institutional investors, earnings information quality, corporate governance

\section{Introduction}

Institutional investors are becoming an important force in Chinese capital market. Recently many scholars are greatly concerned about whether the growing number of institutional investors can improve corporate governance structure? In view of the important role of accounting information quality in corporate governance, we will study the impact of institutional investors on the quality of accounting information. In fact, there is a complementary relationship between accounting information and corporate governance. on the one hand, the quality of information disclosure plays a decisive role in the governance structure of listed companies. On the other 
hand, information disclosure is also an important window to reflect the level of corporate governance. As an important part of corporate governance, accounting information is a link between major shareholders, board of directors, executives and external investors. Large shareholders, all levels of directors and external investors use accounting earnings information to understand the company's operating conditions and value changes in their investment and accordingly supervise the performance of executive management. In turn, an effective corporate governance structure ensures that shareholders receive real and effective information about the company's operations. At the same time reasonable corporate governance provides effective incentive and helps to motivate corporate managers. Finally it will protect the interests of most investors. Therefore, the quality of information disclosure plays a decisive role in the governance structure of listed companies. Meantime the information disclosure is also an important window to reflect the level of corporate governance. Based on these logical analyses, this paper study institutional investors' impact on earnings information quality, and further analyze its supervision role in corporate governance system.

Information disclosure quality of Chinese listed companies is generally low. To some extent this phenomenon also shows that Chinese corporate governance structure is not perfect, which give managers the opportunity to manipulate accounting earnings. Therefore, in order to improve the quality of earnings information, we must strengthen shareholders' supervision to corporate events and managers. For minority shareholders, they lack the protection of the law, coupled with monitoring cost, and tend to be "free rider". They are unable to implement effective supervision to listed companies. Instead institutional investors have the professional competence and capital advantage to participate the supervision of listed companies. This paper takes institutional investors as the research object. Much theoretical analyses show that institutional investors can improve corporate governance level. We use the quality of earnings information to measure the company's governance level, and with empirical test method prove that institutional investors can improve the company's earnings information quality.

We select non-financial listed companies of Chinese capital market as sample from 2012 to 2014, and try to explore the relationship between institutional investors' holdings and accounting earnings quality. The empirical results show that the earnings quality of listed companies with institutional participation is significantly higher than those of other companies after controlling the corresponding factors. And the proportion of institutional investors is significantly positively correlated with earnings quality.

\section{Literature review}

Warfield et al. (1995) measure the value relevance of earnings (or earning information content) using the correlation coefficient between the 
stock return and corporate earnings. They found that the proportion of management's shareholding is positively related to the value relevance of earnings information. At the same time, they also found that the increase in the shareholding of the management shares or institutional investors would reduce agency costs and correspondingly decrease the likelihood that the managers would manipulate the profit figures. Bushman et al. (2000) have found that there is a negative relationship between ownership concentration of American listed companies and the timeliness of earnings. Ball (2000) argues that the earnings disclosures are much more timely for those companies in which corporate governance structures show managers are more detached from other stakeholders, with high external shareholder holdings and active institutional participation in corporate governance.

The research results of LaPorta et al. (1998) and Bushman et al. (2000) show that when financial accounting systems provided less useful information, the company would need much more high-cost shareholders' supervision. Yeo et al. (2002) studied listed companies in Singapore and found that the value of accounting information does not necessarily increase with the increase in the proportion of management shares. The relationship between these two variables is not linear. The shareholding ratio of the external non-related interest groups has an impact on the earnings information. It proved that external interest groups provide an important supervisory role in the corporate governance of Singapore.

The increase in shareholding ratio of non-related interest groups reduces managers' earnings management opportunities. These studies show that the synergistic assumptions of interest are positively related to the value of earnings information. Jiambalvo et al. (2002) found that with the increase in institutional investor holdings, the share price reflects more current earnings information and is conducive to forecasting future earnings. The proportion of institutional investors Significant is positively correlated with the extent to which the share price reflects earnings information. With the increase in the holdings of institutional investors, the current earnings information can be fully reflected into the stock price. The more the proportion of institutional investors' holdings, the higher the accuracy of its earnings forecasting is.

Firth et al. (2002) used total discretionary accruals to measure accounting information quality. They came to a conclusion that the greater the holdings of institutional investors, the less are the amount of discretionary accrual profit that can be manipulated. Their conclusions confirmed institutional investors' role in controlling management earnings manipulation. Soo and Kwon (2002) selected the securities of Korean listed companies from 1993 to 1998 as a sample.They used earnings quality to measure accounting information quality and explored the effect of institutional investors on the quality of accounting information. They finally found that the major 
shareholders and the level of institutional investors 'holdings can have a great impact on the quality of accounting information. And they are positively proportional to the accuracy of accounting information. Especially when the earnings is positive, their influence on the quality of accounting information and the explanation of the model are increasing. Sharma (2004) argued that the company's financial fraud was related to the proportion of institutional investors. After researching the financial fraud of Australian companies, they found that the higher the proportion of corporate institutional investors, the less likely the financial fraud is. On the same hand, Mitra and Cready (2005) concluded that the company's discretionary accrual profit was inversely proportional to the proportion of institutional investors after controlling the company's information environment and scale. Institutional investors could play an active supervisory role in financial reporting. Thus they largely reduced the company's corruption practices. These evidences are enough to prove that institutional investors can play an important role in restraining and supervising the management, which fundamentally enhance the quality of listed companies accounting information.

To sum up, domestic and foreign institutional research is very concerned about role of institutional investors in corporate governance. With the development of institutional investors, more and more research found that institutional investors can participate in the governance of listed companies. However, some Chinese scholars have made empirical analysis on the governance effect of institutional investors on the listed companies according to the capital market data of China. Many research found that institutional investors can improve the governance of the company and play an active supervisory role. At the same time as the proportion of institutional holdings, the greater is their governance role. From the perspective of earnings information to measure the role of institutional investors in the study of corporate governance, some foreign researchers believe that institutional investors can play a supervisory role in listed companies to improve the company's accounting information quality. And domestic research is from a number of perspectives to study this issue. Some studies that when institutional investors reach a certain proportion, they have an impact on corporate accounting information. And some studies that institutional investor's shareholding ratio is proportional to corporate accounting information quality. And some studies that different types of institutional investors on the company's accounting information quality are not the same. With Chinese encouragement of regulatory policies and expansion of securities market, institutional investors have also achieved great development. Institutional investors have the power and ability to supervise the governance of listed companies. Since earnings information is an important basis for investors' investing decision-making, from accounting information quality point of view 
it is very meaningful to examine institutional investors' governance role of listed companies.

\section{Hypothesis development}

Grossman and Hart, and Shleifer and Vishny argue that the larger the investment, the stronger the investor's ability to supervise listed companies. Institutional investors' investment funds are higher than those of average small investors. With large size of the investment stocks, they have more power to supervise the listed companies. Compared with the average small investors, institutional investors have the advantage of information. On the one hand, institutional investors are willing to invest resources to take the initiative to collect information. On the other hand, institutional investors may also have non-public information. Under the support of professional research team and rich information channel institutional investors have a stronger information interpretation and value assessment capabilities than ordinary investors. They have the ability to distinguish whether the accounting policy of listed companies is reasonable and then take the responsibility of certain supervisory role. This kind of supervisory role of institutional investors is much more necessary under the conditions that the current market mechanism of minority shareholders is not well protected; information disclosure and news media are not perfect.

Institutional investors' strong demand for accounting information and reasonable supervision will force the company to reduce profit manipulation and other acts of damage to the fairness of accounting information, thereby improving the quality of accounting earnings. Foreign related research also confirmed this point of view. Chung, Firth and Kim's research results show that institutional investors can reduce the degree of earnings management of listed companies. Their research found that institutional investors' holdings can reduce the company's discretionary accrual profits. And as the proportion of institutional investors holdings increase, the company's discretionary accrual profit gradually reduced. Chidambaran and John's research indirectly indicates the supervisory role of institutional investors. They found that institutional investors' holdings conveyed positive information about the company to the capital market, meaning that the company had more information disclosure and greater transparency, helping to strengthen investors' trust in the company. McConnell and Servaes 'research found that there is a significant positive correlation between institutional investors' shareholding and corporate value. Institutional investors are able to monitor and constrain opportunistic behavior of the firm's management and thereby increase the value of the firm. There are few studies on the influence of institutional investors on the quality of accounting earnings in China. 
From behavioral finance, principal-agent theory and property right theory, theoretically institutional investors are much more active than small investors. We find that the institutional investors with higher shareholding have the potential motivations to actively participate in corporate governance and assume supervisory role. And then they promote the improvement of earnings quality of listed companies. By further analysis of institutional investors, institutional investors have strong profit pressures and their own regulatory strength, which make institutional investors not easy to sale out stocks to exit. Therefore, under the support of professional research team and rich information channel, institutional investors with high shareholding ratio are active and capable. Under the combined effect of "stuck" motivation, profit incentive and policy encouragement, they show positive behavior of shareholders, and then assume a certain role in supervision, and promote the improvement of earnings quality of listed companies.

Reviewing the literature, we conclude institutional investors can effectively monitor the earnings management behavior of listed companies. De-Fond and Jiambalvo (1991) found that when the company had institutional investors that holdmore than $5 \%$ of the outstanding shares, the possibility of a prior change in profitability by management decreased. Dechow (1996) found that in companies with more institutional holdings, the probability of financial fraud is reduced. Rajgopal and Venkatachalam (1997) find that the institutional investors' shareholding is negatively correlated with the absolute value of subjective accruals. Bushee (1998) has found that when the proportion of institutional investors is high, management is less likely to reduce $\mathrm{R} \& \mathrm{D}$ expense. This indicates that institutional investors are mature investors and supervise managers' short-sighted actions to avoid earnings manipulation. To sum up, we put forward the hypothesis that the proportion of institutional investors and the quality of earnings information are positively related. The higher the proportion of institutional investors, the better is the quality of earnings information of listed companies. Since we measure the earnings information of listed companies from two different perspectives using information disclosure rating and earnings smoothness, we can get the following two hypotheses:

H1a: the higher the proportion of institutional investors' holdings, the higher is the information disclosure rating of listed companies.

H1b: the higher the proportion of institutional investors' holdings, the lower is the earnings smoothness of listed companies.

\section{Research design}

\subsection{Sample selection and data resources}

We select 2012-2014 company data listed in Chinese Shanghai and Shenzhen stock markets. We get a total of 6120 Observations after excluding 
the financial class companies, ST class and PT class a total of 6120 observations and companies in which financial data are missing or incorrect data. We use these 6120 observations as a sample for earnings smoothness measure of earnings quality. Because the Shanghai Stock Exchange did not listed companies on the information disclosure rating, for disclosure credit rating measure, we select 2012-2014 company data only listed in Chinese Shenzhen stock markets. Using the same excluding method, we get a total of 3180 observations. All the data comes from WIND (China) financial database. Data are processed by using SPSS software.

\subsection{Variable selection and model design}

Dependent variables

This paper focuses on the impact of institutional investors on the earnings information of listed companies, so we need to find variables that can measure the earnings quality of listed companies as our explained variables. In this study, we measure companies' earnings information quality from two aspects:

(1) Information disclosure quality rating of listed companies, provided by the Shenzhen Stock Exchange (RANK)

(2) We use model to estimate earnings smoothness (ES) as a measure of information disclosure quality of listed companies.

Since 2001, the Shenzhen Stock Exchange evaluates information disclosure quality of listed companies from four aspects of timeliness, accuracy, integrity and legitimacy as a basis for rating. Rating results are divided into four categories: excellent, good, passing and failing. We correspondingly We use this rating as an indicator of the quality of information disclosure. Higher level of disclosure indicates better quality of information for listed companies. In this paper, as for information disclosure rating, we use the ordered logistic regression model to institutional investors 'influence. If the rank is $A$, the assigned value is 1

When the rank is D, the assigned value is 4 .That is, the higher the level of information disclosure, the lower is the value of RANK.

Bhattacharya et al. (2003) measured earnings information quality using earnings smoothness. This study also uses this measurement to examine institutional investors' impact on earnings management. Earnings smoothness (ES) is measured by the ratio of net cash flow variability of operating activities to the degree of profit variation of listed companies. The higher the earnings smoothness, the lower is the degree of accounting information transparency of listed companies.

Independent variables and control variables

1. Institutional Investor Shareholding (INS) 
The proportion of institutional investors holding the shares at the end of the year is the total number of shares held by all institutional investors divided by the total share capital.

According to the existing research, the factors that may affect the quality of earnings information include debt ratio, return on net assets, firm size, state-owned nature, ownership concentration, type of auditing firm, earnings per share, etc. These factors are controlled to ensure the reliability of the results, the control variables are as follows:

1. Debt ratio (LEV): Total debt at the end of the period divided by total assets at the end of the period. This control variable measures the company's financial risk.

2. Return on net assets (ROE): current profit divided by current net assets. This control variable measures the company's operating profitability.

3. Company size (SIZE): the logarithm of the company's total assets. This variable controls the size of the company.

4. State-owned nature (STATE): When the company's largest shareholder is a state-owned shareholder, the value of this control variable is 1 , otherwise 0 .

5. Ownership concentration (HER): the sum of squares of the top ten shareholders' holding ratio.

6. Auditing firm type (AUD): When the company's annual report is audited by the big four accounting firms, the value of this control variable is 1 , otherwise 0 .

7. Earnings per share change ( $\triangle$ EPS): the earnings per share change between current year and previous year.

All variables are defined in Table 1 below

Table 1 Related Variables Definition

\begin{tabular}{|l|l|l|}
\hline & variable & definition \\
\hline \multirow{5}{*}{$\begin{array}{l}\text { Dependent } \\
\text { variable }\end{array}$} & RANK & $\begin{array}{l}\text { Information disclosure quality rating of listed } \\
\text { companies, provided by the Shenzhen Stock Exchange } \\
\text { (for grade A,B,C,D, the value is 1,2,3,4 respectively). }\end{array}$ \\
\cline { 2 - 3 } $\begin{array}{l}\text { Independent and } \\
\text { control variable }\end{array}$ & ES & $\begin{array}{l}\text { Earnings smoothness. The ratio of cash flow variation to } \\
\text { the degree of profit variation of listed companies. }\end{array}$ \\
\cline { 2 - 3 } & SIZE & $\begin{array}{l}\text { All institutional investors' holding divided by total share } \\
\text { capital at the end of the year. }\end{array}$ \\
\cline { 2 - 3 } & ROE & The natural logarithm of the company's total assets \\
\cline { 2 - 3 } & LEV & $\begin{array}{l}\text { Net income divided by shareholders' equity } \\
\text { Total liability divided by total asset }\end{array}$ \\
\cline { 2 - 3 } & STATE & $\begin{array}{l}\text { If the company is state-owned, the value is 1, otherwise } \\
\text { 0. }\end{array}$ \\
\cline { 2 - 3 } & HER & $\begin{array}{l}\text { The sum of squares of the top ten shareholders' } \\
\text { holding ratio. }\end{array}$ \\
\cline { 2 - 3 } & $\begin{array}{l}\text { When the company's annual report is audited by the } \\
\text { big four accounting firms, the value of this control } \\
\text { variable is 1, otherwise } 0 .\end{array}$ \\
\hline
\end{tabular}




\begin{tabular}{|l|l|l|}
\hline$\Delta$ EPS & $\begin{array}{l}\text { The difference between Earnings per share for the } \\
\text { current year and the earnings per share for the previous } \\
\text { year, then divided by last year earnings per share }\end{array}$ \\
\hline
\end{tabular}

\subsection{Research model design}

In this paper, the descriptive statistical analysis of the variables is carried out, and the correlation between the variables is tested. We carry out the linear regression of the aggregated data for 2012-2014. Research model is established to test the proportion of institutional investors and other control factors which have Impact on earnings information quality.

For the hypothesis H1a, we build the model as follows:

RANK $={ }^{\beta_{0}}+{ }^{\beta_{1}} *$ INS $+\beta_{2} *$ SIZE $+\beta_{3} *$ ROE $+\beta_{4} *$ LEV $+\beta_{5} *$ STATE $+\beta_{6}$ $* \mathrm{HER}+\beta_{7} * \mathrm{AUD}+\beta_{8} * \Delta \mathrm{EPS}+{ }_{9} * \sum \mathrm{INDUSTRY}+\beta_{10} * \sum \mathrm{YEAR}+\varepsilon$

This model is an ordered logistic regression model, in which RANK for the Shenzhen Stock Exchange information disclosure rating, there are four categories of ratings, namely, A, B, C, D, respectively, assigned 1,2,3,4. We assume that the higher the proportion of institutional investors, the higher is the company's information disclosure rating.

That is, if the coefficient ${ }^{\beta_{1}}$ is negative, the results of the empirical test in line with our expectations. Industry and YEAR are respectively controlled. For the hypothesis $\mathrm{H} 1 \mathrm{~b}$, research model is established as follows:

$\mathrm{ES}=\beta_{0} \beta_{1} * \mathrm{JGCG}+\beta_{2} *$ SIZE $+\beta_{3}$ ROE $+\beta_{4} * \mathrm{LEV}+\beta_{5} *$ STATE $+\beta_{6}$ $* \mathrm{HER}+\beta_{7} * \mathrm{AUD}+\beta_{8} * \Delta \mathrm{EPS}+{ }_{9} * \sum$ INDUSTRY $+\beta_{10 * \sum \mathrm{YEAR}+\varepsilon}$

Where $\mathrm{ES}$ is calculated as $\mathrm{ES}=\operatorname{DEV}\left(\sum_{\mathrm{k}=\mathrm{t}-2}^{\mathrm{t}} \mathrm{CFO}_{\mathrm{K}} /\right.$ $\left.\operatorname{ASSET}_{\mathrm{K}}\right) / \operatorname{DEV}\left(\sum_{\mathrm{k}=\mathrm{t}-2}^{\mathrm{t}} \operatorname{EARN}_{\mathrm{K}} / \operatorname{ASSET}_{\mathrm{K}}\right)$

$E_{A R N_{t}}$ is the net profit of the company for year $t$.

CFO is the operating cash flow of the company for year $t$.

ASSETt is the total asset of the company for year $t$.

$\operatorname{DEV}\left(\sum_{\mathrm{k}=\mathrm{t}-2}^{\mathrm{t}} \mathrm{CFO}_{\mathrm{K}} / \operatorname{ASSET}_{\mathrm{K}}\right)$ :The standard deviation between the net cash flow and the total assets during the period $(\mathrm{t}-2, \mathrm{t})$

$\operatorname{DEV}\left(\sum_{\mathrm{k}=\mathrm{t}-2}^{\mathrm{t}} \mathrm{EARN}_{\mathrm{K}} / \mathrm{ASSET}_{\mathrm{K}}\right)$ :The standard deviation of net profit and total assets during $(\mathrm{t}-2, \mathrm{t})$

We assume that the higher the proportion of institutional investors, the

lower is the company's earnings smoothness. That is, if the coefficient $\beta_{1}$ is negative, the results of the empirical test in line with our expectations. 


\section{Empirical results}

This section provides descriptive statistics to visualize the distribution of data. The results are shown in Table 2. From the table we can see listed companies on the Shenzhen Stock Exchange with an average credit rating of 1.91 , close to information disclosure grade $\mathrm{B}$, and the median is 2 . This result indicates that at least half of the listed company's information disclosure rating is good. The difference between the listed company's earnings smoothness is very large, the maximum value of 388.79 , while the minimum value is only 0.01 , which indicates that the listed company earnings information quality difference is relatively large. Chinese institutional holdings proportion is at the average $40.63 \%$, which indicates that listed companies account for a large part of institutional investors. While the fund holdings of the average ratio of $5.82 \%$, indicating that the proportion of fund holdings is still relatively small, there is room for further development.

In this paper, we also provide empirical results to examine the relationship between the institutions' shareholding and the quality of earnings information. We use the logistic regression of model 1 and perform multiple regressions according to model 2 . The regression results are shown in Table 3.From the empirical regression results of model 1, it can be seen that there is a significant negative correlation between the proportion of institutional investors and RANK, which means that H1a is established. Higher proportion of institutional investors' holding can improve companies 'information disclosure rating level. As for control variables, the return on net assets, financial leverage, the nature of the company, earnings per share, auditing firm are significant at $1 \%$ descriptive level, which means higher return on net assets ,higher financial leverage ratio are positively related with information disclosure credit rating. At the same time State-owned enterprises, lower earnings per share change, and big four auditing firms are also positively related with information disclosure credit rating.From the empirical regression of model 2, it can be seen that the proportion of institutional investors' holdings and earnings smoothness are significantly negative, which indicates that the proportion of institutional investors reduce earnings smoothness, and $\mathrm{H} 1 \mathrm{~b}$ is established.

Table 2 Descriptive Statistics

\begin{tabular}{|l|l|l|l|l|l|}
\hline & Mean & St.Dev & Median & Max & Min \\
\hline RANK & 1.91 & 0.57 & 2.00 & 4.00 & 1.00 \\
\hline ES & 6.51 & 16.47 & 2.46 & 388.79 & 0.01 \\
\hline INS & 40.63 & 23.72 & 41.79 & 95.46 & 0.00 \\
\hline SIZE & 22.06 & 1.28 & 21.86 & 28.51 & 19.03 \\
\hline ROE & 0.07 & 0.12 & 0.07 & 0.74 & -3.20 \\
\hline LEV & 0.44 & 0.21 & 0.44 & 1.05 & 0.01 \\
\hline STATE & 0.42 & 0.49 & 0.00 & 1.00 & 0.00 \\
\hline
\end{tabular}




\begin{tabular}{|l|l|l|l|l|l|}
\hline HER & 0.17 & 0.12 & 0.15 & 0.76 & 0.00 \\
\hline$\triangle$ EPS & -0.06 & 0.36 & -0.01 & 4.38 & -5.38 \\
\hline AUD & 0.06 & 0.23 & 0.00 & 1.00 & 0.00 \\
\hline ACT & 0.02 & 0.18 & 0.00 & 4.86 & 0.00 \\
\hline NEG & 1.78 & 2.90 & 0.40 & 22.82 & -4.86 \\
\hline
\end{tabular}

Table 3 Regression Results of Institutions 'shareholdings on Earnings Information Quality

\begin{tabular}{|c|c|c|c|}
\hline coefficient & Model 1 & \multicolumn{2}{|l|}{ Model 2} \\
\hline Intercept & $-2.9321 * *$ & \multicolumn{2}{|l|}{-2.7537} \\
\hline INS & $-0.0072 * * *$ & \multicolumn{2}{|c|}{$-0.0004 * * *$} \\
\hline SIZE & $0.0640 *$ & \multicolumn{2}{|c|}{-0.0635} \\
\hline ROE & $-6.6729 * * *$ & \multicolumn{2}{|l|}{2.1838} \\
\hline LEV & $1.0749 * * *$ & \multicolumn{2}{|c|}{$7.5389 * * *$} \\
\hline STATE & $-0.4767 * * *$ & \multicolumn{2}{|c|}{0.2784} \\
\hline HER & -0.0913 & \multicolumn{2}{|l|}{-0.3609} \\
\hline$\Delta$ EPS & $0.4081 * * *$ & \multicolumn{2}{|c|}{1.8516 *** } \\
\hline AUD & $-0.6712 * * *$ & \multicolumn{2}{|c|}{$-3.0655^{* * *}$} \\
\hline INDUSTRY & Control & \multicolumn{2}{|c|}{ Control } \\
\hline YEAR & Control & \multicolumn{2}{|l|}{ Control } \\
\hline $\mathrm{N}$ & 3810 & \multicolumn{2}{|l|}{6120} \\
\hline LR stat & 489.67 & $\mathrm{R}^{2}$ & 0.0422 \\
\hline R-squared & 0.0764 & Adjusted $\mathrm{R}^{2}$ & 0.0379 \\
\hline Prob & $0.00 * * *$ & $\mathrm{~F}$ & 9.9477 \\
\hline
\end{tabular}

$* * *$ significant at the $1 \%$ level $* *$ significant at the $5 \%$ level *significant at the $10 \%$ level

From the empirical regression of model 1 , it can be seen that there is a significant negative correlation between the proportion of institutional investors and RANK, which means that H1a is established, that is, the higher the proportion of institutional investors' Improve the company's credit disclosure level. From the return of control variables, the return on net assets, the balance sheet, the nature of the company, earnings growth per share, whether the four major audits and corporate credit disclosure rating at $1 \%$ level, which is the return on net assets High, high gearing ratio, state-owned enterprises, low earnings per share growth, the four major audit companies, the higher the credit rating.

From the empirical regression of model 2, it can be seen that the proportion of institutional investors and the holdings of ES are negative, but not significant, indicating that the proportion of institutional investors is not affected by the surplus, indicating that H1b is not established.

To sum up, the overall shareholding ratio of institutional investors has a significant impact on information disclosure credit rating. The increase in institutional shareholding ratio can improve the company's information disclosure credit rating. At the same time, institutional investors also affect earnings smoothness. The increase in institutional shareholding ratio reduces 
the degree of earnings smoothness, which further improves information disclosure quality.

\section{Research conclusion}

This paper discusses the impact of institutional investors on the earnings information of listed companies from the theoretical and empirical perspectives. On the basis of the theoretical analysis, this paper chooses the listed companies of Shanghai and Shenzhen A shares as the research samples from 2012 to 2014, and studies the impact of the proportion of institutional investors' shareholding on earnings information quality of listed companies. The conclusion of this paper is as follows: the higher the proportion of institutional investors, the higher is the credit rating of information disclosure quality, and the lower is the earning smoothness degree.

From the empirical results, there is a significant positive correlation between the proportion of institutional investors and the credit rating of listed companies, and the increase in the proportion of holders of institutions can improve the company's credit disclosure rating. At the same time, the proportion of institutional investors' shareholding is negatively related to earning smoothness. It is noteworthy that there are a variety of institutional investors diversified in the size, expertise and resources. Combined with different level of corporate governance of the company, it is worthy of further research about different type of institutional investors 'impact on earnings information quality.

With the growth of institutional investors, the institutional shareholders promote the improvement of earnings information quality through the participation of corporate governance, which will become the future unstoppable trend. Therefore, Chinese capital market can improve corporate governance by vigorously developing institutional investors. In view of the research results of this paper and the current situation of institutional investors in China, we put forward the following policy recommendations. Firstly, vigorously develop institutional investors to improve the company's governance level. With the rapid rise of capital markets, institutional investors continue to grow and develop. In the capital market they will also show more and more strong influence. The rise of institutional investors can avoid "free rider" phenomenon from individual investors and strengthen the level of corporate governance, but also to avoid individual investors because the shareholding ratio is too low, weak weaknesses. Secondly, China should develop positive institutional investors to improve the quality of corporate earnings information.

The use of positive institutional investors will promote the development of capital markets.It can be seen from the research of this paper 
that positive institutional investors have a positive effect on the quality of earnings information of listed companies.

\section{References:}

1. W Taylor. Can Big Owners Make a Big Difference?. Harvard Business Review,1990, (7): :70-82

2. Velury Uma. The effect of Institutional Ownership on the Quality of Earnings. The Ph.D Dissertation University of South Carolina,1999.

3. Sharma Vineeta D: Board of director characteristics, institutional ownership, and fraud:evidence from Australia. Auditing: a Journal of Practice \&Theory,2004, (2)

4. Renneboog L. Ownership, managerial control and the governance of companies listed on the Brussels stock exchange. Journal of Banking and Finance, 2000, (24):1959-1995

5. Rajgopal S, M Venkatachalam. The Role of Institutional Investors in Corporate Governance: An Empirical Investigation. Working Paper University of Washington,1997, (4) :1-36

6. Mitra,Santanu, Cready. Institutional Stock Ownership, Accrual Management,and Information Environment. Journal of Accounting,Auditing\&Finance,2005,20, (3) :257-286

7. Dechow P., Sloan R., A. Sweeney. Causes and Consequences of Earnings Manipulation: An Analysis of Firms Subject to Enforcement Actions by the SEC $[\mathrm{J}]$. Contemporary Accounting Research, 1996,13(1):1-36

8. Porter M. E. Capital Disadvantage: America's Failing Capital Investment System[J]. Harvard Business Review, 1992,70(5):65-82

9. Cheng C. S. A., Reitenga A. L. Characterisitcs of Institutional Investors and Discretionary Accruals[R]. SSRN Working Paper, http://ssrn.com/abstract=277717, 2001

10. Bushee B. J. The Influence of Institutional Investors on Myopic R\&D Investment Behavior[J]. The Accounting Review, 1998,73(3):305-333

11. DeFond M., Jiambalvo J. Incidence and Circumstances of Accounting Errors[J]. The Accounting Review, 1991,66(3):643-655

12. Bushee, B ., 2001 , "Do Institutional Investors Prefer Near-term Earnings over Long-run Value?”, Contemporary Accounting Research 18

13. Bushman, Chen, E. Engel and A. Smith, 2000b, "The Sensitivity of Corporate Governance Systems to the Timeliness of Accounting Earnings",Working paper, University of hicago 
14. Warfield,J. Wild, K. Wild.,1995,"Managerial Ownership,Accounting Choices and in Formativeness of Earnings", Journalof Accounting and Economics, (20), pp.61 91.

15. Ball, R., S. Kothari and A. Robin.,2000,“The Effect of International Institutional Factors on Properties of Accounting Earnings",Journal of Accounting and Economic, 29(1), pp.1 51.

16. Brickley J. Ownership Structure and Voting on Antitrade over Amendments. Journal of Financial Economics,1998, (20): 267-297

17. Coffee J. Liquidity versus control the Institutional Investor as corporate monitor.

18. Columbia law Review,1991，(1): :1277-1368

19. Gorton G M, Kahl Blocholder. Identity Equity Ownership Structure and Hostile

20. Takeover. Working Paper,1999,1-63

21. Jensen M C,W H Meckling. Theory of The Firm: Managerial Behavior,Agency Costs and Ownership Structure. Journal of Financial Economics,1976, (3):305-360

22. Jiambalvo J, S Rajgopal,M Venkatachalam. Institutional ownership and the extent to which stock prices reflect future earnings. Contemporary Accounting Research,2002, (19) : 45-117

23. Kahneman D, Tversky A. Prospect Theory: An Analysis of Decision Risk. Journal of Financial Economics,1979, (47): 263-291

24. Kooyul Jung Soo, Young Kwon. Ownership structure and earnings informativeness:Evidence from Korea. The International Joumal of Accounting, 2002, (37) :301-325 